\title{
A Study on Coevolutionary Relationship of Four Plants With Their Butterfly Pollinators on Basis of Their Nectar Physiology
}

\author{
Meerabai Guddeti ${ }^{1}$ \\ ${ }^{1}$ Department of Botany, Rayalaseema University, Kurnool, India \\ Correspondence: Meerabai Guddeti, Department of Botany, Rayalaseema University, Kurnool-7, A.P., India. \\ E-mail: guddetimeerabai@gmail.com
}

Received: January 12, $2014 \quad$ Accepted: April 2, $2014 \quad$ Online Published: April 18, 2014

doi:10.5539/enrr.v4n2p65 URL: http://dx.doi.org/10.5539/enrr.v4n2p65

\begin{abstract}
Present study is aimed to reveal the co evolutionary relationship of four butterfly pollinated flowers Cadaba fruticosa (L.) Druce, Caesalpinia pulcherrima (L.) Sw., Clerodendrum infortunatum L. and Clerodendrum phlomidis L.f. Not only the floral morphology, nectar quality the main energy source of insects including butterflies is also a promiscuous character which excludes other insects than specified. So, nectar characters of these flowers are studied and found a good correlation with butterfly preferred nectars. Here one-sided adaptation was there and it was described as "non-promiscuous". It is one of the most significant events in organic evolution.
\end{abstract}

Keywords: coevolution, floral morphology, nectar quality, non-promiscuous

\section{Introduction}

The term Coevolution introduced by Ehrlich and Raven (1964) was primarily intended to refer to the nature of chemical and physical differences of plants against herbivory and of the adaptations of insects to these factors. According to these authors, the joint evolution of two or more taxa that have close ecological relationships and in which reciprocal selective pressures operate to make the evolution of either taxon partially dependent on the evolution of the other can be described as Coevolution. Janzen (1980) defined Coevolution as evolutionary change in a trait of the individuals in one population in response to a trait of the individuals of a second population followed by an evolutionary response by the second population to the change in the first. Thus Coevolution includes most of the various forms of population interaction from competition, predation and parasitism to mutualism and cooperation (Odum, 1971; Pianka, 1983). Coevolution is often used to refer to the interdependent evolutionary interactions between plants and their animal pollinators (Pianka, 1983). The plant and the pollinator place evolutionary pressure on each other for changes in morphology, physiology or habits that benefit both. There was no same goal to the plants and pollinators. Plants desire to accelerate the spread of pollen to new individuals and to reduce the energetic costs of nectar and pollen production. But pollinators desire high quality food in the form of proteinacious, sugary nectar and pollen to accelerate energetic rewards and to reduce the cost of foraging. A highly specialized relationship between plant and pollinator symbionts was resulted by this antagonistic goal. The role of co evolution in shaping the relationships between plants with food rewarding flowers and their pollinators is more controversial. It seems that co evolution can operate alongside other one-sided evolutionary processes to shape the traits of interacting species (Johnson \& Anderson, 2010). Mathieu et al. (2001) emphasized essentiality of the study how nectar chemistry is involved in the adaptation to a specific pollinator spectrum and how phylogenetic constraints act on this chemistry. Several authors have suggested that though the nectar features and pollination biology have occurred independently in different lines, the convergence of them is the result of sugar intake efficiency of specific pollinators, their digestive abilities and plant adaptation to preferences (Heyneman, 1983; Martinez del Rio et al., 1992; Baker et al., 1998).

Coevolution can be an important driver of phenotypic divergence among populations of strongly interacting species. It was confirmed by the studies of Pellmyr et al. (1996), Weiblen (2002) and Toju and Sota (2006). Many plants have flowers specialized for a single functional group of pollinators, but it is rare for insect pollinators to specialize on flowers of a particular plant species. This leads to diffuse co evolution at the level of interacting species (Thompson, 1994, 2005).

If Coevolution was an important process in plant - butterfly interaction system, the plants might have been 
expected to evolve so as to preferentially attract butterflies and discourage visits of other insects and/or to evolve morphological characteristics promoting effectiveness of butterflies in transferring pollen. There are four such instances where no other insect species except butterflies are involved. These include Cadaba fruticosa (L.) Druce. Clerodendrum infortunatum L., Clerodendrum phlomidis L.f. and Caesalpinia pulcherrima (L.) Sw. Cadaba fruticosa is pollinated by the Pierid members Colotis eucharis, C.danae and Anaphaeis aurota. The two Colotis species oviposit on the leaves and flower buds and the larvae feed on the same. Therefore the occurrence of coevolution can be imagined in this Cadaba - Colotis system. The flowers of Clerodendrum phlomidis and of Caesalpinia pulcherrima are pollinated by both Papilionids and Pierids and of Clerodendrum infortunatum are by only Papilionids.

To determine the co evolutionary relationship of these plants with their butterfly pollinators, the morphological adaptations of the flowers and nectar characteristics like concentration, quantity of amino acids and presence of proteins in nectars are studied. Nectars are the chief energy sources of various insects and they rely on nectars of flowers. So, nectar quality is one of the significant properties which have to be considered.

\section{Material and Methods}

\subsection{Study Site}

The study was carried in two selected areas where plenty of green vegetation serving as foliar and floral hosts was existing. They are (1) Andhra University campus which enjoys both natural and plantations and (2) The Indira Gandhi Zoological Park and its surroundings with protected forest area.

\subsection{Data Collection}

The study was conducted for two years. During the study period, these four plant species visited by butterflies were collected and identified with the help of floras. The form of a flower which plays an important role in attracting the insects was recorded. The structural arrangements of floral parts were noted. In order to know the appropriateness of a flower for manipulation by a butterfly, length of nectar tubes of flowers and proboscis length of butterfly pollinators of the studied flowers were measured.

The butterflies were identified by referring to Wynter-Blyth's (1957) "Butterflies of the Indian region". To study the nectar characters, the nectar accumulated in the flowers covered with butter paper bags was collected with graduated micropipettes and used. The nectar sugar concentration was determined by using Refractometer. The collected nectar was expelled onto the prism of Refractometer and the percent concentration was readout. Analysis of nectar for the type of sugars present was done by paper chromatography (Harborne, 1973). The presence and the relative amounts of amino acids in nectars were determined following the method of Baker and Baker (1973a). The presence of proteins in the nectars was indicated by the development of greenish blue color when Brom - phenol - blue stain was placed on the nectar spot put and dried on the filter paper.

\section{Results and Discussion}

Plant - Pollinator relationships are determined by floral morphology and its inherent features such as volume, concentration, viscosity and chemical composition (Heinrich \& Raven, 1972; H. G. Baker \& I. Baker, 1983a; Kingsolver \& Daniel, 1983; Proctor et al., 1996). Studies of H. G. Baker and I. Baker (1983b), Freeman et al. (1984), Lammers and Freeman (1986), Elisens and Freeman (1988), H. G. Baker and I. Baker (1990), Stiles and Freeman (1993), Baker et al. (1998) suggested that sucrose - rich nectar been found mostly in flowers pollinated by hummingbirds or insects with long mouthparts viz. butterflies, moths and long tongued bees.

The results of nectar tube lengths, range of proboscis lengths of butterfly pollinators, average concentration of nectars, histidine scales showing amino acids and presence of proteins for four plants are provided in a Table 1. The results are very much coincided with butterfly flower nectar qualities as reported by earlier studies. Measurements of nectar tube lengths and the proboscis lengths of butterfly pollinators supports the view of Johnson and Anderson (2010), who said that selection often strongly favors plants with floral tubes that exceed the length of their pollinators tongues. There is also evidence that pollinators gain an energetic benefit from having tongues that enable them to consume most or all of the nectar in deep tubular flowers.

Horizontally oriented flowers possessing rather elongated staminal filaments and style facilitate comfortable landing of butterflies. Such a device also excludes other potential flower visitors (Percival, 1965). Flowers of Cadaba fruticosa, Caesalpinia pulcherrima, Clerodendrum phlomidis and Clerodendrum infortunatum are designed in this way and it is certain that contact between the essential organs and wings is established when the butterfly visits the flower. Presence of sexual organs and nectar source separated in space is a device of positive value for the correct use and placing of the proboscis by the butterflies (Percival, 1965; Faegri \& Pijl, 1979; Cruden \& Hermann-Parker, 1979). Such floral design is seen in Cadaba fruticosa and Caesalpinia pulcherrima. 
H. G. Baker and I. Baker (1973a) demonstrated that butterfly nectars are sucrose rich. So also the nectar of Caesalpinia pulcherrima, a butterfly flower (Cruden \& Hermann-Parker, 1979). The present study showed that the nectars of these four plants are sucrose dominated.

Researchers showed that the volume of nectar provided by a flower is just a secondary consideration within certain limits and the primary determinant of their preference is the concentration of energy giving chemicals and quality of amino acids in nectar (Neff et al., 1977; Baker, 1978). H. G. Baker and I. Baker (1973) reported that butterfly nectars are not very viscous. A wide range exists in the concentration of nectars utilized by butterflies as reported by different investigators: 15-25\% (Watt et al., 1974), 13-44\% (Baker, 1975), 16-40\% 9 (Baker, 1978), 20-25\% (Kingsolver \& Daniel, 1979) and 40-65\% (Pivnick \& McNiel, 1985). The present study revealed that the average nectar concentrations ranging between $16-25 \%$ in all the four species.

Naturally butterfly nectars are rich in amino acids and of amino acid score on histidine scale reported by $\mathrm{H}$. G. Baker and I. Baker (1973a, 1973b) and Baker (1978) ranged between 4-10, the mean being 6.68. The scores of histidine scale of the nectars of Cadaba fruiticosa (5.5), Caesalpinia pulcherrima (6.0), Clerodendrum infortunatum (6.0) and Clerodendrum phlomidis (4.0) fall within the range predicted for butterfly nectars. Proteins present in nectars provide nitrogenous rich food. Pauw et al. (2009) confirmed that directional selection on tongue length could potentially occur through an energetic benefit.

While these plant taxa are totally dependent on these butterfly species for their reproductive success, the butterflies themselves do not confine their visits solely to these species. Though it is hard to imagine the occurrence of Coevolution in this system, there is one-sided adaptation in that these flowers are designed for manipulation by butterflies alone. The pollinators were all heavily dependent on these abundant plants as a source of food. Thus it can be imagined that the process of reciprocal selection operates.

According to Thompson (2005) co evolutionary relationships should also have geographically variable outcomes when community structure differs. According to Johnson and Anderson (2010) co evolutionary problems cannot be solved by studying single species at single sites and require comparative approaches that include studies of whole guilds of interacting species across their geographical ranges.

The kind of pollination that is being affected exclusively by butterflies in above four plant taxa is described as "non promiscuous" and is a necessary precondition for the rise of floral isolating mechanism (Grant, 1949). Establishment of this relationship is one of the most significant events in the organic evolution.

\section{Conclusion}

The study revealed that the floral morphology of the four plants Cadaba fruticosa, Ceaslpinia pulcherrima, Clerodendrum phlomidis and Clerodendrum infortunatum appears highly labile and contrasts with the great similarity of sugar composition and concentration measured in the butterfly flowers led to the conclusion for existence of the co evolutionary relationship with their butterfly pollinators.

Table 1. Showing dominent sugar in nectar, average nectar concentrations, histidine scale showing amino acids and protein presence in studied plants

\begin{tabular}{|c|c|c|c|c|c|c|c|}
\hline S. No. & Name of the Plant & $\begin{array}{c}\text { Predominant } \\
\text { sugar }\end{array}$ & $\begin{array}{c}\text { Nectar } \\
\text { concentration } \\
\text { in } \%\end{array}$ & $\begin{array}{c}\text { Histidine } \\
\text { scale showing } \\
\text { amino acids }\end{array}$ & $\begin{array}{l}\text { Proteins } \\
\text { presence }\end{array}$ & $\begin{array}{c}\text { Nectar tube } \\
\text { length of the } \\
\text { flower (in mms.) }\end{array}$ & $\begin{array}{c}\text { Range of } \\
\text { proboscis lengths } \\
\text { of butterfly } \\
\text { visitors (in mms.) }\end{array}$ \\
\hline 1. & $\begin{array}{l}\text { Cadaba fruticosa } \\
\text { (L.) Druce }\end{array}$ & Sucrose & 19 & 5.5 & + & 7 & $17-22$ \\
\hline 2. & $\begin{array}{c}\text { Caesalpinia } \\
\text { pulcherrima } \\
\text { (L.).Sw. }\end{array}$ & Sucrose & 23 & 6.0 & + & 16 & $22-27$ \\
\hline 3. & $\begin{array}{l}\text { Clerodendrum } \\
\text { infortunatum L. }\end{array}$ & Sucrose & 16 & 6.0 & + & 25 & $17-32$ \\
\hline 4. & $\begin{array}{l}\text { Clerodendrum } \\
\text { phlomidis L.f. }\end{array}$ & Sucrose & 25 & 4.0 & + & 16 & $16-22$ \\
\hline
\end{tabular}




\section{References}

Baker, H. G. (1975). Sugar concentrations in nectars from hummingbird flowers. Biotropica, 7, 37-41. http://dx.doi.org/10.2307/2989798

Baker, H. G. (1978). Chemical aspects of the pollination biology of woody plants in the tropics. In P. B. Tomlinson \& M. H. Zimmerman (Eds.), Tropical trees as living systems (pp. 57-82). Cambridge: Cambridge University press.

Baker, H. G., \& Baker, I. (1973a). Some anthecological aspects of the evolution of nectar producing flowers, particularly amino acid production in nectar. In V. H. Heywood (Ed.), Taxonomy and Ecology (243-264). London-New York: Academic Press.

Baker, H. G., \& Baker, I. (1973b). Amino acids in nectar and their evolutionary significance. Nature (Lond.), 241, 543-545. http://dx.doi.org/10.1038/241543b0

Baker, H. G., \& Baker, I. (1978). Studies of nectar constitution and pollinator - plant co evolution. In L. E. Gilbert \& P. H. Raven (Eds.), Coevolution of animals and plants (pp. 100-140). Austin: University of Texas press.

Baker, H. G., \& Baker, I. (1983a). A brief historical review of the chemistry of floral nectar. In B. Bentley \& T. Elias (Eds.), The biology of nectarines (pp. 126-152). New York. Columbia University press.

Baker, H. G., \& Baker, I. (1983b). Floral nectar sugar constituents in relation to pollinator type. In C. E. Jones \& R. J. Little (Eds.), Handbook of experimental pollination biology (pp. 117-141). New York: Van Nostrand Reinhold.

Baker, H. G., \& Baker, I. (1990). The predictive value of nectar chemistry to the recognition of pollinator types. Israel Journal of Botany, 39, 157-166.

Baker, H. G., Baker, I., \& Hodges, S. A. (1998). Sugar composition of nectar and fruits consumed by birds and bats in the tropics and subtropics. Biotropica, 30, 559-586. http://dx.doi.org/10.1111/j.1744-7429.1998.tb00097.x

Cruden, R. W., \& Hermann-Parker, S. M. (1979). Butterfly pollination of Caesalpinia pulcherrima, with observations on a psychophilous syndrome. Journal of Ecology, 67, 155-158. http://dx.doi.org/10.2307/2259342

Ehrlich, P. R., \& Raven, P. H. (1964). Butterflies and plants: a study in co evolution. Evolution, 18, 586-588. http://dx.doi.org/10.2307/2406212

Elisens, W. J., \& Freeman, C. E. (1988). Floral nectar sugar composition and pollinator type among New World genera in tribe Antirrhineae (Scrophulariaceae). American Journal of Botany, 75, 971-978. http://dx.doi.org/10.2307/2443763

Faegri, K., \& Pizl, L. Van der. (1979). The principles of pollination ecology (3rd revised Ed.). Oxford: Pergamon press.

Freeman, C. E., Reid, W. H., Beevar, J. E., \& Scogin, R. (1984). Similarity and apparent convergence in the nectar-sugar composition of some hummingbird-pollinated flowers. Botanical Gazette, 145, 132-135. http://dx.doi.org/10.1086/337436

Grant, V. (1949). Pollination systems as isolating mechanisms in angiosperms. Evolution, 3, 82-97. http://dx.doi.org/10.2307/2405454

Harborne, J. B. (1973). Phytochemical methods. London: Chapman and Hall. http://dx.doi.org/10.1016/0031-9422(73)80722-8

Heinrich, B., \& Raven, P. H. (1972). Energetics and pollination ecology. Science, 176, 597-602. http://dx.doi.org/10.1126/science.176.4035.597

Heyneman, A. J. (1983). Optimal sugar concentration of floral nectars-dependence on sugar intake efficiency and foraging costs. Oecologia, 60, 198-213. http://dx.doi.org/10.1007/BF00379522

Janzen, D. H. (1980). When is it Co evolution? Evolution, 34, 611-612. http://dx.doi.org/10.2307/2408229

Johnson, S. D., \& Anderson, B. (2010). Co evolution between Food - Rewarding Flowers and Their Pollinators. Evo. Edu. Outreach, 3, 32-39. http://dx.doi.org/10.1007/s12052-009-0192-6

Kingslover, J. G., \& Daniel, T. L. (1983). Mechanical determinants of nectar feeding strategy in 
hummingbirds:energetics, tongue morphology, and licking behavior. Oecologia, 60, 214-226. http://dx.doi.org/10.1007/BF00379523

Kingsolver, J. G., \& Daniel, T. L. (1979). On the mechanics and energetics of nectar feeding in butterflies. $J$. Theor. Biol., 76, 167-179.

Lammers, T. G., \& Freeman, C. E. (1986). Ornithophily among the Hawaiian Lobelioideae (Campanulaceae): evidence from floral nectar sugar composition. American Journal of Botany, 73, 1613-1619. http://dx.doi.org/10.2307/2443929

Martinez, del Rio C., Baker, H. G., \& Baker, I. (1992). Ecological and evolutionary implications of digestive processes: Bird preferences and sugar constituents of floral nectar and fruit pulp. Experientia, 48, 544-551. http://dx.doi.org/10.1007/BF01920237

Neff, D. L., Simpson, B. B., \& Moldenke, A. R. (1977). Flowers - flower visitor system. In G. H. Oriens \& O. T. Solbrig (Eds.), Convergent evolution in warm deserts (pp. 204-224). Stroudsburg: Dowden, Hutchinson and Ross. Inc.

Odum, E. P. (1971). Fundamentals of Ecology. Philadelphia, London, Toronto: W. B. Saunders Company.

Pauw, A., Stofberg, J., \& Waterman, R. J. (2009). Flies and flowers in Darwin's race. Evolution, 63, 268-79. http://dx.doi.org/10.1111/j.1558-5646.2008.00547.x

Pellmyr, O., Thompson, J. N., Brown, J. M., \& Harrison, R. G. (1996). Evolution of pollination and mutualism in the Yucca moth lineage. Am. Nat., 148, 827-847. http://dx.doi.org/10.1086/285958

Percival, M. (1965). Floral biology. Oxford, London, Edinburgh, New York, Paris, Frankfurt: Pergamon press.

Pianka, E. R. (1983). Evolutionary ecology. New York, Hagers-town, San Francisco, London: Harper and Row publishers.

Pivnick, K. A., \& McNiel, J. N. (1985). Effects of nectar concentrations on butterfly feeding: measured feeding rates for Thymelicus lineola (Lepidoptera; Hesperiidae) and a general feeding model for the adult Lepidoptera. Oecologia (Berl.), 66, 226-237.

Proctor, M., Yeo, P., \& Lack, A. (1996). The natural history of pollination. Portland: Timber Press.

Stiles, F. G., \& Freeman, C. E. (1993). Patterns in floral nectar characteristics of some bird-visited plant species from Costa Rica. Biotropica, 25, 191-205. http://dx.doi.org/10.2307/2389183

Thompson, J. N. (1994). The Coevolutionary process. Chicago: Chicago University Press. http://dx.doi.org/10.7208/chicago/9780226797670.001.0001

Thompson, J. N. (2005). The geographic mosaic of co evolution. Chicago: University of Chicago Press.

Toju, H., \& Sota, T. (2006). Imbalance of predator and prey armament: Geographic clines in phenotypic interface and natural selection. Am. Nat., 417, 735-738.

Watt, W. B., Hoch, D. C., \& Hills, S. G. (1974). Nectar resource use by Colias butterflies, chemical and visual aspects. Oecologia (Berl.), 14, 353-374. http://dx.doi.org/10.1007/BF00384578

Weiblen, G. D. (2002). How to be a fig wasp. Annu. Rev. Entomol., 47, 297-330. http://dx.doi.org/10.1146/annurev.ento.47.091201.145213

Wynte-Blyth, M. A. (1957). Butterflies of the Indian region. Bombay: Bombay Nat. Hist. Soc.

\section{Copyrights}

Copyright for this article is retained by the author(s), with first publication rights granted to the journal.

This is an open-access article distributed under the terms and conditions of the Creative Commons Attribution license (http://creativecommons.org/licenses/by/3.0/). 